\title{
Calcitonin Secretion in Congenital Nongoitrous Cretinism
}

\author{
Dennis E. Carey, Kenneth Lee Jones, Jacqueline G. Parthemore, and \\ LeOnaRd J. Deftos, Departments of Pediatrics and Medicine, \\ University of California, San Diego, School of Medicine and the San Diego \\ Veterans Administration Medical Center, La Jolla, California 92093
}

\begin{abstract}
A B S T R A C T Plasma calcitonin (CT) was measured in the basal state and/or during provocative tests of hormone secretion in 11 children with congenital nongoitrous cretinism (CNC), in 1 girl with a lingual thyroid, and in 11 normal children. Basal and stimulated CT concentrations were significantly lower in the patients with CNC than in the normal subjects. Mean basal CT $( \pm \mathrm{SE})$ was $41 \pm 4 \mathrm{pg} / \mathrm{ml}$ in the normal children, $24 \pm 3 \mathrm{pg} / \mathrm{ml}$ in the children with CNC, and $20 \pm 2 \mathrm{pg} / \mathrm{ml}$ in the patient with the lingual thyroid. The mean incremental CT responses to calcium infusion were $7.0 \pm 2 \mathrm{pg} / \mathrm{ml}$ in the children with CNC, $6.0 \mathrm{pg} / \mathrm{ml}$ in the patient with the lingual thyroid, and $146 \pm 47 \mathrm{pg} / \mathrm{ml}$ in the normal children. The children with CNC also demonstrated a significant delay in the return of the total serum calcium to basal level after the calcium infusion. The mean incremental CT response after infusion of pentagastrin was $7.6 \pm 2 \mathrm{pg} / \mathrm{ml}$ in the children with CNC, $10.0 \mathrm{pg} / \mathrm{ml}$ in the child with the lingual thyroid, and $34.4 \pm 11 \mathrm{pg} / \mathrm{ml}$ in the normal children. These data indicate that CT deficiency is present in children with $\mathrm{CNC}$ and suggest that the deficiency is a consequence of the defective embryologic development of the thyroid gland.
\end{abstract}

\section{INTRODUCTION}

In mammals, the calcitonin-producing cells $(\mathrm{C} \text { cells })^{1}$ of the thyroid gland become incorporated into that organ during embryogenesis after their migration from the neural crest (1). In patients with congenital dysgenesis of the thyroid, the thyroid gland is poorly developed or absent, and thus may not be available as the organ of residence for the $\mathrm{C}$ cells. In order to study the effect of this developmental thyroid abnormality on

\footnotetext{
Address reprint requests to Dr. Deftos, 3350 La Jolla Village Drive, San Diego, Calif. 92161.

Received for publication 20 August 1979 and in revised form 26 December 1979.

${ }^{1}$ Abbreviations used in this paper: C-cell, calcitoninproducing cell; CNC, congenital nongoitrous cretinism; CT, calcitonin; $\mathrm{P}_{1}, \mathrm{P}_{2}, \mathrm{P}_{3}, \mathrm{P}_{5}$, pubertal stages; $\mathrm{TSH}$, thyrotropin.
}

C-cell function, we studied calcitonin (CT) secretion in children with congenital nongoitrous cretinism (CNC).

\section{METHODS}

Subjects. 23 children were studied after parental consent had been obtained. The study had the approval of the Human Subjects Committee of the University of California, San Diego.

Basal blood samples for plasma CT determination were obtained from 11 normal children who had no abnormalities of calcium or skeletal metabolism and from 11 children with CNC. The normal group consisted of six boys and five girls who ranged in age from 3 to $12 \mathrm{yr}$ (mean age $9.2 \mathrm{yr}$ ). These were children who were having blood drawn during routine physical examination (basal sample only) and siblings of children undergoing provocative testing. None of the normal children had any clinical evidence of hypothyroidism or other thyroid disease. The hypothyroid group consisted of two boys and nine girls who ranged in age from 1.25 to $15 \mathrm{yr}$ (mean age $7.9 \mathrm{yr}$ ). Children from each group also underwent provocative testing of CT secretion. Calcium and pentagastrin infusion studies were performed on five normal children, four boys and one girl (mean age $9.0 \mathrm{yr}$ ), and seven children with CNC, two boys and five girls (mean age $9.1 \mathrm{yr}$ ). Of the nine girls in the CNC group, seven had a pubertal stage $P_{1}$, one had $P_{3}$, and one had $P_{5}(2)$. Of the five girls in the control group, two were $P_{1}$ and three were $P_{2}$. A 2.5-yr-old girl with a lingual thyroid also received both infusions.

The clinical profiles of the children who underwent provocative testing are given in Table $\mathrm{I}$. The diagnosis of thyroid agenesis was demonstrated in four nongoitrous cretins by the absence of thyroid tissue during either $\mathrm{Tc}^{99 \mathrm{~m}}$-pertechnetate (3) or radioiodine scanning. In two additional patients with severe mental retardation the diagnosis of thyroid dysgenesis was made on the basis of elevated thyrotropin (TSH) levels before therapy (patient 10) or after cessation of therapy (patient 12). Patient 7, a moderately retarded male, was diagnosed at 11 wk of age with the typical clinical presentation of congenital hypothyroidism, no goiter, and several abnormally low thyroxine values. Thyroid scanning and TSH determination were not obtained before the institution of therapy in this child. In three of the four patients in whom only a basal CT level was obtained, the clinical diagnosis was confirmed by thyroid scanning. The patients were euthyroid at the time of the study except patient 10 who was studied before any therapy and patient 12 who was hyperthyroid as a result of an excessive replacement dosage. There was no evidence of renal disease in any of these patients.

Procedures. All of the studies were performed in the morning after an overnight fast. An infusion of $3 \mathrm{mg} / \mathrm{kg}$ body 
TABLE I

Clinical Profile of Children who Underwent Provocative Testing

\begin{tabular}{|c|c|c|c|c|c|c|c|c|c|c|}
\hline & \multirow[b]{2}{*}{ Age } & \multirow[b]{2}{*}{ Sex } & \multirow[b]{2}{*}{$\begin{array}{l}\text { Pubertal* } \\
\text { staging }\end{array}$} & \multicolumn{4}{|c|}{ Laboratory } & \multicolumn{3}{|c|}{ Study period } \\
\hline & & & & $\begin{array}{c}\text { Basal } \\
\text { calcium }\end{array}$ & $\mathrm{T} 4 \mathrm{t}$ & TSH & $\begin{array}{c}\text { Thyroid\$ } \\
\text { scan }\end{array}$ & $\mathrm{T}^{\prime \prime}$ & TSH & Treatment \\
\hline & & & & $(m g / d l)$ & $\mu g / d l$ & $\mu U / m l$ & & $\mu g / d l$ & $\mu U / m l$ & \\
\hline \multicolumn{11}{|c|}{ Patients } \\
\hline 6 & 6 & $\mathbf{M}$ & $P_{1}$ & 9.95 & - & - & 0 & 11.6 & 4.0 & $100 \mu \mathrm{g}$ \\
\hline 7 & 6 & M & $P_{1}$ & 8.76 & 5.3 & - & NP & 8.6 & 1.2 & $11 / 4$ grains \\
\hline 8 & 9 & $\mathrm{~F}$ & $P_{1}$ & 9.91 & 4.4 & $>150$ & 0 & 12.2 & 3.1 & $100 \mu \mathrm{g}$ \\
\hline 9 & 8 & $\mathrm{~F}$ & $\mathrm{P}_{1}$ & 10.17 & 1.0 & - & 0 & 10.8 & 2.6 & $11 / 2$ grains \\
\hline 10 & 6 & $\mathrm{~F}$ & $P_{1}$ & 9.40 & $<1.5$ & $>60$ & NP & $<1.5$ & $>60$ & None \\
\hline 11 & 15 & $\mathrm{~F}$ & $\mathrm{P}_{5}$ & 10.74 & 0.1 & $>100$ & 0 & 6.0 & - & $150 \mu \mathrm{g}$ \\
\hline 12 & 15 & $\mathrm{~F}$ & $\mathrm{P}_{3}$ & 9.78 & 3.1 & $>60$ & NP & $17.6^{* *}$ & 0.4 & $200 \mu \mathrm{g}$ \\
\hline 13 & $21 / 2$ & $\mathrm{~F}$ & $P_{1}$ & 9.87 & 6.5 & 15 & LT & 6.5 & 15 & None \\
\hline \multicolumn{11}{|c|}{ Normal Subjects } \\
\hline 1 & 12 & M & $\mathrm{P}_{1}$ & 8.90 & & & & & & \\
\hline 2 & 10 & $\mathrm{M}$ & $\mathrm{P}_{1}$ & 9.13 & & & & & & \\
\hline 3 & 6 & $\mathbf{M}$ & $\mathrm{P}_{1}$ & 9.32 & & & & & & \\
\hline 4 & 6 & $M$ & $\mathrm{P}_{1}$ & 9.68 & & & & & & \\
\hline 5 & 11 & $\mathrm{~F}$ & $\mathrm{P}_{2}$ & 9.56 & & & & & & \\
\hline
\end{tabular}

* Pubertal staging defined in reference 2.

$\$$ Thyroxine measured by several methods. All values were below the lower limit of normal for the assay employed.

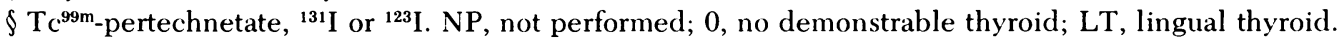

"Thyroxine radioimmunoassay.

I Treatment as either synthroid (micrograms) or dessicated thyroid (grains).

** Excessive replacement dosage at time of study was subsequently reduced.

wt elemental calcium (as calcium chloride) was administered over $10 \mathrm{~min}$. Blood samples were collected at $0,5,10,20$, 30,40 , and $60 \mathrm{~min}$ after the initiation of the infusion. Immediately after the 60-min sample, an intravenous bolus of pentagastrin (Peptavlon, Ayerst Laboratories, New York) at a dose of $0.5 \mu \mathrm{g} / \mathrm{kg}$ body wt was administered. Blood samples were collected at 2, 5, 10, 20, 40, and $60 \mathrm{~min}$. During the calcium infusion heart rate was followed by cardiac monitoring and no abnormalities were observed.

Analytical procedures. Heparinized samples for CT determinations were immediately placed in ice and the separated plasma stored at $-20^{\circ} \mathrm{C}$ until assayed. Plasma CT was determined by a previously described radioimmunoassay $(4,5)$. This procedure can detect $1 \mathrm{pg}$ of $\mathrm{CT} / \mathrm{ml}$ of plasma and does not demonstrate the presence of CT in thyroidectomized subjects. Total serum calcium was determined by atomic absorption spectrophotometry (Perkin-Elmer 403, PerkinElmer Corp., Instrument Div., Norwalk, Conn.) or EDTA titration (Corning 20 calcium analyzer, Corning Medical, Corning Glass Works, Medfield, Mass.).

Calculations. Statistical analyses were performed with the Student's $t$ test (6). Data in the test and figures are presented as the mean $\pm \mathrm{SE}$.

\section{RESULTS}

Basal calcitonin. Basal CT values are presented in Fig. 1. The mean basal plasma CT $( \pm \mathrm{SE})$ in children with CNC $(24 \pm 3 \mathrm{pg} / \mathrm{ml})$ was significantly $(P<0.005)$ less than that of the normal children $(41 \pm 4 \mathrm{pg} / \mathrm{ml})$. The basal CT in the girl with the lingual thyroid (Table I, patient 8) was $20 \pm 2 \mathrm{pg} / \mathrm{ml}$.
Effect of calcium and pentagastrin on plasma calcitonin and serum calcium. Fig. 2 illustrates the effect of calcium infusion and pentagastrin infusion on plasma CT and serum calcium in the normal subjects and the patients. Calcium infusion produced a mean increment of plasma CT in normal children (146 47 $\mathrm{pg} / \mathrm{ml})$ which was significantly $(P<0.007)$ greater than that of the children with CNC $(7.0 \pm 2 \mathrm{pg} / \mathrm{ml})$. All of the normal subjects demonstrated a peak plasma CT response at $10 \mathrm{~min}$ whereas this was seen in only two of the seven patients.

The mean total serum calcium concentrations for both groups were within the normal range prior to the

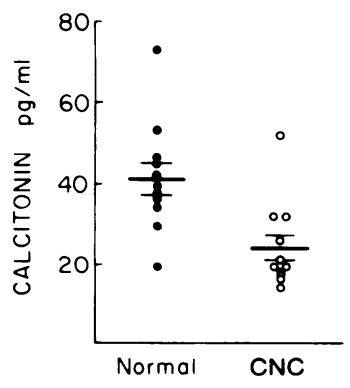

FIgure 1 Basal plasma CT in 11 nomal children and 11 children with $\mathrm{CNC}(\mathrm{O})$. Mean $\pm \mathrm{SE}$ indicated by horizontal lines. 


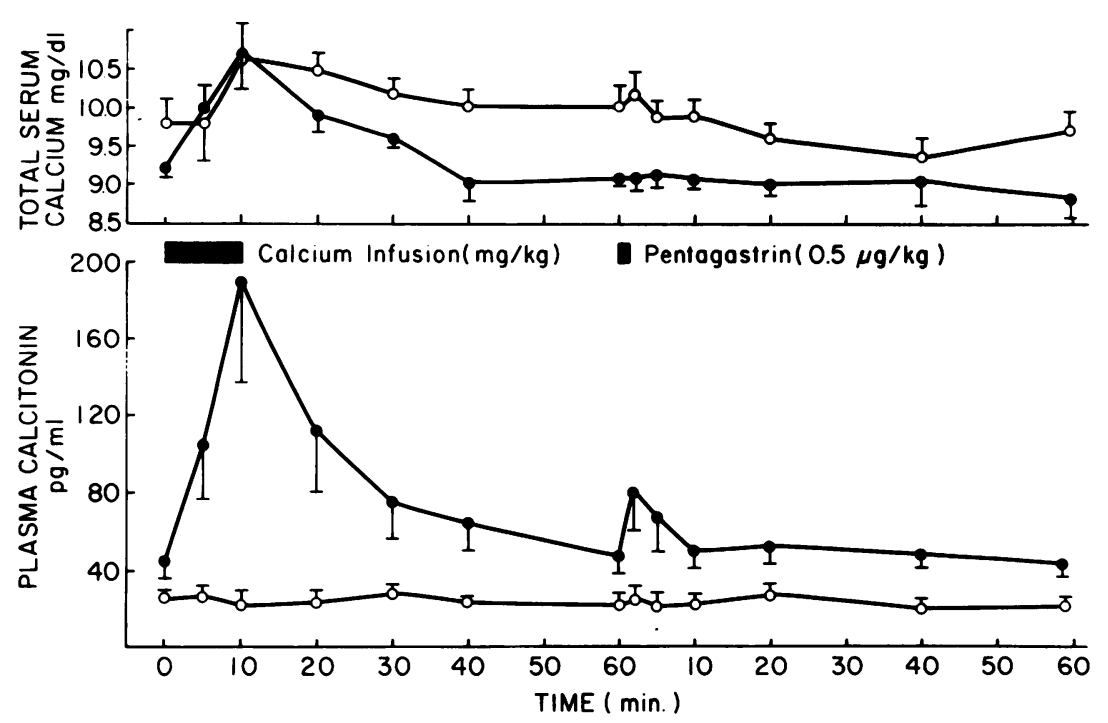

FIGURE 2 Plasma CT and total serum calcium during and after calcium and pentagastrin infusion in five normal children (O) and in seven children with CNC (O).

calcium infusion. Although the value for the children with CNC $(9.8 \pm 0.7 \mathrm{mg} / 100 \mathrm{ml})$ was greater than that for the normal children $(9.23 \pm 0.3 \mathrm{mg} / 100 \mathrm{ml})$, the difference was not significant. However, the pattern of decline in total serum calcium differed in the two groups. In the normal groups the mean total serum calcium decreased to below the base-line level by 40 min. In the patient group, on the other hand, it had not returned to base line by $60 \mathrm{~min}$ and remained significantly $(P<0.05)$ increased over that of the control group at both 40 and $60 \mathrm{~min}$.

Pentagastrin infusion also produced a mean increment in plasma CT in normal children $(34.4 \pm 11 \mathrm{pg} / \mathrm{ml})$ which was significantly $(P<0.025)$ greater than that of children with CNC $(7.6 \pm 2 \mathrm{pg} / \mathrm{ml})$. The peak plasma CT occurred at $2 \mathrm{~min}$ in four of five normal subjects but only in two of seven patients.

Calcium and pentagastrin studies were also performed in an euthyroid girl with a lingual thyroid (Table I-patient 13). This child demonstrated CT and calcium responses that were similar to those of the patients with CNC. The maximum increase in plasma CT was $6 \mathrm{pg} / \mathrm{ml}$ after the calcium infusion and $10 \mathrm{pg} / \mathrm{ml}$ after the pentagastrin infusion. The mean total serum calcium concentration remained above the base line for 60 min after the calcium infusion.

\section{DISCUSSION}

Our results demonstrate that children with CNC have lower than normal levels of plasma CT in the basal state and during provocative testing with two known CT secretagogues, calcium and pentagastrin. Because CT can act to lower blood calcium, this CT deficiency may explain why the children with congenital cretinism are less able than the normal children to rapidly correct the hypercalcemia induced by the calcium infusion, an observation similar to that of Anast and Guthrie (7). In addition, the pattern of stimulated CT secretion in the congenital cretin group was also different from that observed in the normal children. In normal children, the peak plasma CT response occurred within a consistent time period after the initiation of each infusion. In the CNC group, the peak response was erratic and occurred later than in the normal group. Thus, children with CNC not only have significantly lower plasma CT concentrations than normal children but also have CT secretory responses which differ qualitatively from those observed in normal children. Pentagastrin infusion elicited a smaller CT response than calcium infusion. Because pentagastrin was administered $1 \mathrm{~h}$ after the calcium infusion, this smaller response may be explained by a decreased response of the $\mathrm{C}$ cells to the second of two stimuli of close temporal proximity.

These studies allowed us to compare the basal and stimulated plasma CT concentrations in normal children to those in adults. Although basal CT levels in children have been reported to be greater than adult levels by several investigators (8-10), we found the levels in the small group of normal children of this study to be indistinguishable from those previously observed by us in adults (5). By contrast, our data demonstrate that there are differences in stimulated CT secretion between normal children and adults. After calcium infusion normal children had a 4.4-fold mean increase in plasma CT whereas normal adults previously studied in a similar manner had only a twofold mean increase. Extensive expansion of the present study will be necessary to define the differences in CT secretion between children and adults and to 
determine if age- and sex-related differences in CT secretion are present in normal children.

The CT deficiency in these children with hypothyroidism may be the result of either quantitative or qualitative C-cell abnormalities. There are no data regarding C-cell numbers in congenital thyroid dysgenesis. However, the thyroid does play an important role in the embryogenesis of $\mathrm{C}$ cells in mammals. These $\mathrm{C}$ cells are derived from neural crest elements present in the fourth pair of pharyngeal pouches (1). During embryogenesis in mammals these neural crest elements migrate to the developing thyroid and become disseminated among the follicular cells. (In submammals, the C cells form their own organ, the ultimobranchial gland.) A physiologic interaction between the $\mathrm{C}$ cells and the thyroid follicular cells has been suggested (11). The similarity of the poor secretory response observed in both the children with congenital cretinism and the patient with the lingual thyroid suggests that the CT deficiency in these children may be due not only to the absence of thyroid tissue but also to the failure of normal thyroidal migration and failure of incorporation of $\mathrm{C}$ cells into a normally situated thyroid gland.

The demonstration of CT deficiency in children is of particular interest because there is evidence that CT may play an important role in the regulation of skeletal metabolism during childhood. Wolfe, et al. (12), have demonstrated $\mathrm{C}$ cells in the normal neonatal thyroid gland to be relatively greater in number and to have greater CT content than those of the normal adult. Elevated levels of plasma CT have been described in neonates $(9,13,14)$ and in cord blood compared with matched maternal blood (8).

Despite CT deficiency or undersecretion, children with thyroid dysgenesis have no obvious disorder of calcium metabolism and the typical skeletal abnormalities of this disease appear to be corrected by thyroid hormone replacement. Nonetheless, an unappreciated mineral abnormality may be present in these children. Our data suggest that comprehensive evaluation of calcium homeostasis and skeletal metabolism should be considered to determine any pathophysiological consequence of decreased calcitonin secretion in children with congenital thyroid dysgenesis.

\section{ACKNOWLEDGMENTS}

The authors appreciate the assistance of Kathy Caneer, Linda Nelson, and Carolyn Robinson. Ciba Geigy Corp., Pharma- ceuticals Div., Summit, N. J. provided generous support for these studies. We are particularly grateful to the nurses and staff of the Clinical Research Center of University Hospital, San Diego, Calif. (RR00827), for the excellent care given to our patients.

This study was supported by the National Institutes of Health (grants AM 15888, and AM25604), the American Cancer Society, and the Veterans Administration. Dr. Carey is supported in part by grant A.M0748 from the National Institutes of Health.

\section{REFERENCES}

1. Weichert, R. F., III. 1970. The neural ectodermal origin of the peptide-secreting endocrine glands. Am. J. Med. 49: $232-241$.

2. Kelch, R. P., M. M. Grumbach, and S. L. Kaplan. 1972. Mechanisms of puberty in man. In Gonadotropins. B. B. Saxena, C. G. Beling, and H. M. Gandy, editors. WileyInterscience Div. John Wiley \& Sons, Inc., New York. $524-533$.

3. Hayek, A., R. A. Bauman, and J. D. Crawford. 1971. ${ }^{99 \mathrm{~m}} \mathrm{Tc}$ pertechnetate for detection of cryptic thyroid tissue in childhood hypothyroidism. J. Pediatr. 79: 466-468.

4. Parthemore, J. G., and L. J. Deftos. 1978. Calcitonin secretion in normal human subjects. J. Clin. Endocrinol. Metab. 47: $184-188$

5. Parthemore, J. G., and L. J. Deftos. 1979. Calcitonin secretion in primary hyperparathyroidism. J. Clin. Endocrinol. Metab. 49: 223-227.

6. Snedecor, G. W., and W. G. Cochran. 1967. Statistical Methods. Iowa State University Press, Ames, Iowa. 6th edition.

7. Anast, C. S., and R. A. Guthrie. 1971. Decreased calcium tolerance in nongoitrous cretins. Pediatr. Res. 5: 668-672.

8. Samaan, N. A., G. D. Anderson, and M. D. Adam-Mayne. 1975. Immunoreactive calcitonin in the mother, neonate, child, and adult. Am. J. Obstet. Gynecol. 121: 622-625.

9. Dirksen, H. C., and C. S. Anast. 1976. Interrelationship of serum immunoreactive calcitonin $(i C T)$ and serum calcium in newborn infants. Pediatr. Res. 11: 1180-1185. (Abstr.)

10. Shainkin-Kerstenbaum, R., B. Funkenstein, A. Conforti, S. Shani, and G. M. Berlyne. 1977. Serum calcitonin and blood mineral interrelationships in normal children aged six to twelve years. Pediatr. Res. 1: 112-116.

11. Nunez, E. A., and M. D. Gershon. 1978. Cytophysiology of thyroid parafollicular cells. Int. Rev. Cytol. 52: 1-80.

12. Wolfe, H. J., R. A. DeLellis, E. F. Voelkel, and A. H. Tashjian. 1975. Distribution of calcitonin containing cells in the normal neonatal thyroid gland: a correlation of morphology with peptide content. J. Clin. Endocrinol. Metab. 41: 1076-1081.

13. David, L., and C. S. Anast. 1973. Serum immunoreactive calcitonin $(i \mathrm{CT})$ in newborn. Pediatr. Res. 7: 386. (Abstr.)

14. Bergman, L., I. Kjelimer, and U. Selstam. 1974. Calcitonin and parathyroid hormone-relation to early neonatal hypocalcemia in infants of diabetic mothers. Biol. Neonate. 24: 151-159. 